[19] Commission Regulation 466/2001 of 8 March 2001 fixing maximum levels for certain contaminants in foodstuffs.

[20] Neklesa, O., Yarantseva, Y., Pyvovarov, Y., Grinchenko, O. (2017). Study of Constructive Provision of the Capsule Formation Process of the "Oil and Fat Raw Materials - Ionotropic Shell-Maker" System. EUREKA: Physics and Engineering, 6, $42-47$. doi: http://doi.org/10.21303/2461-4262.2017.00508

\title{
RESEARCH OF RATIONAL CONCENTRATION OF OILSEED CROPS MEALS IN THE SANDY DOUGH SEMI-FINISHED PRODUCT
}

\author{
Mihailo Kravchenko \\ Department of technology and restaurant establishment organization \\ Kyiv National University of Trade and Economics \\ 19 Kioto str., Kyiv, Ukraine, 02156 \\ Vitalii Mihailik \\ Department of technology and restaurant establishment organization \\ Kyiv National University of Trade and Economics \\ 19 Kioto str., Kyiv, Ukraine, 02156 \\ vetalikk@bigmir.net \\ Dmytro Yakymchuk \\ Department of hotel-restaurant and tourism business \\ Kherson State University \\ 2740 rokiv Zhovtnya str., Kherson, Ukraine, 73000 \\ starcon84@gmail.com \\ Oksana Dzyundzya \\ Department of hotel-restaurant and tourism business \\ Kherson State University \\ 2740 rokiv Zhovtnya str., Kherson, Ukraine, 73000 \\ Mykola Valko \\ Department of food technologies \\ Kherson National Technical University \\ 24 Beryslav highway, Kherson, Ukraine, 73008 \\ Olga Mamai \\ Department of food technologies \\ Kherson National Technical University \\ 24 Beryslav highway, Kherson, Ukraine, 73008 \\ Tatyana Popovich \\ Department of Chemistry and Pharmacy \\ Kherson State University \\ 2740 rokiv Zhovtnya str., Kherson, Ukraine, 73000
}




\author{
Anna Ryabinina \\ Department of Chemistry and Pharmacy \\ Kherson State University \\ 2740 rokiv Zhovtnya str., Kherson, Ukraine, 73000
}

\author{
Lyudmila Vishnevskaya \\ Department of Chemistry and Pharmacy \\ Kherson State University \\ 2740 rokiv Zhovtnya str., Kherson, Ukraine, 73000
}

\title{
Oksana Vitriak
}

Department of technology and restaurant establishment organization

Kyiv National University of Trade and Economics

19 Kioto str., Kyiv, Ukraine, 02156

\begin{abstract}
The work studies the rational concentration of meals of soya, sunflower and milk thistle in a sandy dough semi-product for improving healthy properties of ready products (biological value, stomach peristalsis, metabolism, saturation with vitamins and mineral substances). Analytic studies were conducted and advantages of using meals in dough products were determined. The chemical composition of meals was determined, and the optimal composition for satisfying the human need that is in ratio 3:4:3 was calculated. The quality of meals was estimated, and their organoleptic parameters were analyzed. The sensor analysis of sandy semi-products of oilseed crops meals was realized. It was established, that adding of the meal composition instead of flour in amount $20 \%$ is an optimal solution for using in a sandy dough semi-product.

There was established the influence of meals of oilseed crops on organoleptic parameters of developed sandy semi-products. Advantages and defects of using the aforesaid meals were established. Ways of improving the outlook and consistence of shortcakes were offered. Ways of further studies were established.
\end{abstract}

Keywords: sandy dough semi-product, meals of oilseed crops, dough deformation, meals composition.

\section{Introduction}

It is urgent today to provide health of all people throughout the world. For this it is necessary to improve the ration at the expanse of consuming healthy and relatively cheap food [1]. This task is usually provided by different methods. One of which is to add to food healthy elements that provide the essential improvement of a food value of products [2].

Bakery products occupy an important place among products, continuously consumed because of their small cost and fast saturation of the organism. But modern dough products have low healthy indices because of different causes [3]. It is possible to eliminate this shortcoming at the expanse of adding healthy microelements, one of which is meals.

Meals are side products of oilseed crops grains processing after getting oils from them [4]. Such biologically active supplements are characterized by the powder-like structure and increased content of cellulose, protein, mineral substances and vitamins of B group [5]. There are distinguished flax, sesame, walnut, sunflower meals. Their use provides the daily need of the organism in proteins, mineral substances and macro- and microelements [6, 7].

Meals, comparing with other vegetable raw materials and supplements, are characterized with relatively high protein content - from $20 \mathrm{~g}$ to $45 \mathrm{~g}$ for $100 \mathrm{~g}$ of a supplement $[8,9]$. They contain fat as $4 \mathrm{~g}-10 \mathrm{~g}$ for $100 \mathrm{~g}$. Carbohydrates are from $9 \mathrm{~g}$ to $39 \mathrm{~g}$ for $100 \mathrm{~g}$ of meals [10]. At that the main part of them is food fibers [11, 12].

Soya meal [13-15] is distinguished by the highest content of such microelement as cobalt $31,2 \mathrm{mcg}$. It stimulates formation of hemoglobin and erythrocytes, growth processes, it activates the effect of muscular and bone phosphatase. The human daily need is $100 \mathrm{mcg}$. 
Sunflower meal has the highest fat content among other ones $-12 \mathrm{~g}$, and also sodium -160 mg. Fat as a plastic material participates in cells construction, their especially high content is in membranes. It participates in hormones synthesis, is a high-energetic resource of the organism. The daily need in fat is $80 \mathrm{~g}$. Sodium supports an optimal balance between extracellular and tissue liquids in the organism [16, 17]. It participates in acids neutralization, muscles contraction and blood pressure regulation, gives tissues endurance. Its daily need is $1,3 \mathrm{~g}$.

Milk thistle meal has the highest selenium content. It is a powerful antioxidant. It provides the extremely reliable protection of erythrocytes and cellular membranes from free radicals [18]. Selenium increases the organism's resistance to diseases, increases leucocytes production and protects them from free radicals. The daily need in selenium is $70 \mathrm{mcg}$.

Thus, it is urgent to study the rational concentration of oilseed crop meals in a sandy dough semi-product, as one of most spread at manufacturing sandy products in Ukraine. It allows to establish an optimal ratio between dough and meals and favors production of shortcakes with increased food characteristics.

The aim of the research is to study the rational concentration of meals of soya, sunflower and milk thistle in a sandy dough semi-product for synchronously providing the human daily need in proteins, mineral substances, macro- and microelements.

\section{Materials and Methods} (Ukraine).

The material was meals of soya, sunflower and milk thistle, produced by "PE Myroslav"

The dough elasticity was determined on the Tolstoy elastoplastometer (Ukraine). Test models of study [16] and rheological research methods for raw materials of study [17] were used in the experiments. All raw materials (sandy dough and its ingredients) and materials (meals as a supplement) corresponded to requirements of actual normative documents (SSU 3781:2014) by quality and safety parameters, and also to the quality of firms-producers and are permitted for using by the Health Protection Ministry of Ukraine.

For studying the chemical composition of meals and dough semi-product, there were used existing standard research methods, namely- SSU ISO 771:2006 and SSU 4910:2008. According to SSU ISO 771:2006, there was determined the content of moisture and volatile substances, according to SSU 4910:2008 - methods of determining mass particles of moisture and dry substances for confectionary products [19].

Organoleptic parameters of sandy dough were determined by testing using a ten-point scale, according to SSU 5024:2008 [20]. The material for the studies was soya, sunflower and milk thistle meals (Fig. 1), corresponding to TC U 10.4-38667335-002:2014 [21]. Just they were used in further for creating the composition.

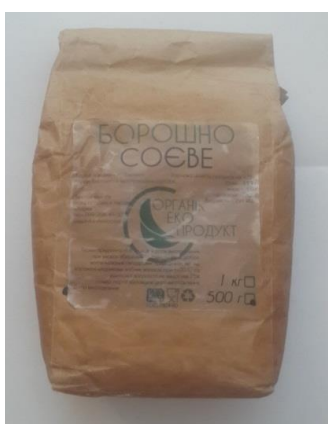

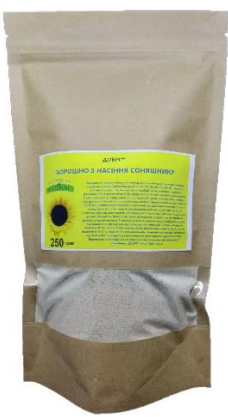

$b$

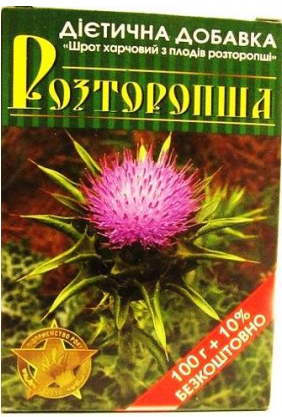

Fig. 1. Meals, used in the experiment: $a$-soya; $b$ - sunflower; $c$ - milk thistle

The research object was one composition of soya, sunflower and milk thistle meals. Using the mathematical modeling method, there was determined the optimal ratio between three types of meals in the composition that was further used for following studies. 
A dough sandy semi-product, which main components were flour, eggs, sugar, salt, soda, ammonium (fluffier), cream butter was selected as a control.

The obtained composition with the ratio of soya, sunflower and milk thistle as 3:4:3 was introduced in sandy dough with its replacement in amount $10 \%, 20 \%$ and $30 \%$ instead of flour in the recipe of sandy dough. The recipe No. 8 (sandy semi-product No. 8 from the collection of recipes of confectionary products [22]) was used at correspondent experiments No. 1 (10\%), No. 2 (20\%) and No. 3 (30\%). For that 4 samples of sandy dough were used with wheat flour of the highest sort and sesame, nut, flax meals that created sandy dough semi-products.

\section{Experimental procedures}

Before conducting the main studies, there were realized preliminary experiments for determining the chemical composition of samples with adding the aforesaid meals. They allowed to outline limits of further experiments. After that, the chemical composition of meals was calculated that is presented in Table 1.

Table 1

Chemical composition of soya, sunflower and milk thistle meals (for $100 \mathrm{~g}$ )

\begin{tabular}{cccc}
\hline Parameters & & Name of meals & Milk thistle meal \\
\cline { 2 - 4 } & Soya meal & Sunflower meal & 20 \\
Protein, g & 44,7 & 40 & 5,5 \\
Fat, g & - & - & 25,2 \\
Carbohydrates, $g$ & 17,6 & 39 & 35 \\
Including cellulose, g & 2,6 & 8 & 920 \\
Potassium, mg & 1600 & 647 & 1660 \\
Calcium, mg & 217 & 367 & 420 \\
Magnesium, mg & 200 & 317 & 4 \\
Sodium, mg & 5 & 160 & 960 \\
Phosphorus, mg & 603 & 860 & 8 \\
Iron, mg & 9 & 6,1 & 9 \\
Iodine, mcg & 8,2 & 22,5 & 10 \\
Cobalt, mcg & 31,2 & 32 & 10
\end{tabular}

Table 1 allows to make conclusions that it is necessary to determine such meals concentration, at which the developed composition will satisfy the daily need in necessary nutrients the best.

At calculating the optimal composition there was firstly taken the ratio of soya, sunflower and milk thistle meals as 3:4:3. At that there was calculated satisfaction of the daily need in such substances as fat that is $0,2 \%$, carbohydrates $-0,5 \%$, phosphorus $-8,44 \%$, iodine $-0,4 \%$, cobalt $-1,18 \%$, manganese $-3,15 \%$, copper $-3,25 \%$. In total satisfaction of the daily need in the composition equals $17,10 \%$.

At the following calculation of the composition, there was taken the ratio of soya, sunflower and milk thistle meals as 4:4:2 and 2:4:4. At that satisfaction of the daily need of such substances as fat is $0,15 \%$ and $0,19 \%$, carbohydrates $-0,56 \%$ and $0,47 \%$, phosphorus $-8,45 \%$ and $8,43 \%$, iodine $-0,34 \%$ and $0,46 \%$, cobalt $-1,37 \%$ and $0,98 \%$, manganese $-3,05 \%$ and $3,24 \%$, copper $3,18 \%$ and $3,33 \%$. In total satisfaction of the daily need in the composition equals $17,05 \%$.

At the ratio of soya, sunflower and milk thistle meals as 4:3:3 satisfaction of the daily need in the correspondent substances is totally $14,80 \%$. The ratio of the aforesaid meals in amount 3:3:4 
and 4:2:4 provides the daily need totally by $14,80 \%$ and $12,50 \%$. In other meal ratios a value of the human daily need in necessary nutrients decreased even more.

Formula (1) was used for determining the necessary concentration of meals in the composition:

$$
Y=A_{1} X_{1}+A_{2} X_{2}+A_{3} X_{3}+\ldots+A_{n} X_{n}
$$

where $A_{1}, A_{2}, A_{3}$ - amount of a correspondent meal in the composition (soya, sunflower and milk thistle) $\% ; X_{1}, X_{2}, X_{3}, \ldots, X_{n}$ - relative content of components in meals (fat, carbohydrates, protein, Phosphorus, iodine, cobalt, manganese, copper, sodium, iron) $\%$ of mass.

The conducted calculations and studies allowed to establish that the best composition of soya, sunflower and milk thistle meals for satisfying the daily need is 3:4:3 ratio.

\section{Results}

For conducting the studies, the meals quality was estimated. Organoleptic parameters of the quality soya, sunflower and milk thistle meals were analyzed (Table 2).

Table 2

Quality estimation of soya, sunflower and milk thistle meals

\begin{tabular}{ccccc}
\hline \multirow{2}{*}{ Meal type } & \multicolumn{4}{c}{ Characteristic } \\
\cline { 2 - 5 } & Color & Smack & Concentration & Smell \\
\hline Milk thistle meal & Light-chocolate & Nut & Homogenous, brittle, & Absent \\
Soya meal & Light-brown & Absent & Typical for walnuts & Typical nut
\end{tabular}

It was noted, that the taste and smell of the studied meals is absent or typical nut that can influence the quality of ready cakes positively. The consistence of meals is homogenous, brittle, powder-like that makes it possible to use them in the sandy dough technology. The color of meal samples is determined from light-chocolate to light-brown that can influence the coloration of ready products. The obtained data confirm the assumption about a possibility of using the chosen meals in the sandy dough technology.

The organoleptic estimation of dough sandy semi-products with the meal composition was studied. The technology of shortcakes by the recipe collection was chosen as a control. Sandy dough, consisted of different ingredients (flour, eggs, sugar, salt, soda, ammonium (fluffier), cream butter) was added with $10 \%, 20 \%$ and $30 \%$ of the composition of soya, sunflower and milk thistle meals instead of flour (experiment No. 1, experiment No. 2, experiment No. 3).

The organoleptic estimation in the developed products was realized by the gustatory commission by existing methods $[23,24]$. It consisted of experts, who made gustatory acts and put marks of the organoleptic parameters - outlook, smell, consistence, color, porosity. 7 testing specialists took part in the studies. 5-point scale for the organoleptic estimation was developed. The highest mark is 5 points. Each organoleptic parameter was given a ponderability coefficient, and gustatory acts were created. Ponderability coefficients were given to each organoleptic parameter by the individual expert commission.

The main parameters of sandy dough that influence the quality of ready cakes are consistence, smell, outlook. So, they get more ponderability coefficient, comparing with other ones. In sum it equals 1. Different descriptors are also used (Table 3).

After that there was conducted the sensor analysis of sandy semi-products of soya, sunflower and milk thistle meals. Each estimation criterion received a point mark and the best result for all experiments was determined. The research results are given in Table 4. 
Table 3

Parameters of sensor analysis of sandy semi-products of soya, sunflower and milk thistle meals

\begin{tabular}{|c|c|c|c|}
\hline Parameter & Ponderability coefficient & Characteristic & Ponderability coefficient \\
\hline \multirow{5}{*}{ Outlook } & \multirow{5}{*}{0,2} & Cracks presence & 0,2 \\
\hline & & Surface evenness & 0,1 \\
\hline & & Surface condition & 0,3 \\
\hline & & Clots absence & 0,2 \\
\hline & & Form stability & 0,2 \\
\hline \multirow{5}{*}{ Porosity } & \multirow{5}{*}{0,2} & Saturation & 0,2 \\
\hline & & Expressiveness & 0,25 \\
\hline & & Raw material correspondence & 0,2 \\
\hline & & pureness & 0,25 \\
\hline & & Homogeneity & 0,1 \\
\hline \multirow{4}{*}{ Smell } & \multirow{4}{*}{0,25} & naturalness & 0,3 \\
\hline & & saturation & 0,25 \\
\hline & & Raw material correspondence & 0,25 \\
\hline & & pureness & 0,2 \\
\hline \multirow{4}{*}{ Consistence } & \multirow{4}{*}{0,25} & Plasticity & 0,25 \\
\hline & & elasticity & 0,3 \\
\hline & & homogeneity & 0,2 \\
\hline & & Fine-dispersion & 0,25 \\
\hline \multirow{4}{*}{ Color } & \multirow{4}{*}{0,1} & Saturation & 0,23 \\
\hline & & Expressiveness & 0,25 \\
\hline & & Raw material correspondence & 0,2 \\
\hline & & Homogeneity & 0,25 \\
\hline
\end{tabular}

Thus, according to the research results (Table 4), the wheat flour replacement in the technology of flour confectionary products by soya, sunflower and milk thistle meals in the amount from $10 \%$ to $30 \%$ unessentially influences the organoleptic parameters of the developed sandy semi-products. The samples of the experiments are inferior to the control one by the unessential value. It testifies to the effectiveness of using meals in dough semi-products.

At adding meals instead of flour in amount $10 \%$ there takes place the unessential worsening of the outlook, consistence and color. The surface evenness, color saturation worsen, plasticity, elasticity and homogeneity decrease.

At adding meals instead of flour in amount $20 \%$ there also takes place the unessential worsening of the outlook, consistence and color. Namely the surface evenness worsens, plasticity, elasticity and homogeneity and also color expressiveness decrease.

At adding meals instead of flour in amount $30 \%$ there takes place the most worsening of the outlook, consistence and color. The surface evenness, smell naturalness decrease noticeably, plasticity and elasticity also decrease. Worst indices of sandy semi-products are observed for such meal concentration.

The outlook and consistence of a control sample of sandy dough is always better than an experimental one. At adding the meal composition, the color changes unessentially, but the dough 
consistence worsens at decreasing flour cellulose. Thus, as far as at adding the meal composition instead of flour in amount $20 \%$ the organoleptic mark of sandy semi-products changes unessentially, so it is an optimal solution to add $20 \%$ of the composition of soya, sunflower and milk thistle meals. At adding the meal composition more than $20 \%$ dough grows darker and is badly mixed that negatively influences the quality of ready products.

Table 4

Results of the sensor analysis of sandy semi-products of soya, sunflower and milk thistle meals

\begin{tabular}{|c|c|c|c|c|c|}
\hline \multirow[b]{2}{*}{ Parameter } & \multirow[b]{2}{*}{ Characteristic } & \multicolumn{4}{|c|}{ Shortcake with replacement of flour by meals of oilseed crops } \\
\hline & & Control & $\begin{array}{c}\text { Experiment No. } 1 \\
(10 \%)\end{array}$ & $\begin{array}{c}\text { Experiment No. } 2 \\
(20 \%)\end{array}$ & $\begin{array}{c}\text { Experiment No. } 3 \\
(30 \%)\end{array}$ \\
\hline \multirow{5}{*}{ Outlook } & Cracks presence & 5,0 & 5,0 & 5,0 & 4,8 \\
\hline & Surface evenness & 5,0 & 4,9 & 4,9 & 4,8 \\
\hline & Surface condition & 4,9 & 4,9 & 4,9 & 4,7 \\
\hline & Clots absence & 5,0 & 4,9 & 4,9 & 4,7 \\
\hline & Form stability & 5,0 & 5,0 & 4,9 & 4,7 \\
\hline \multirow{5}{*}{ Porosity } & Saturation & 5,0 & 4,9 & 4,9 & 4,9 \\
\hline & Expressiveness & 4,9 & 5,0 & 4,9 & 4,7 \\
\hline & Raw material correspondence & 5,0 & 5,0 & 5,0 & 4,7 \\
\hline & pureness & 5,0 & 4,9 & 4,9 & 4,8 \\
\hline & Homogeneity & 4,9 & 4,9 & 4,9 & 4,7 \\
\hline \multirow{4}{*}{ Smell } & naturalness & 5,0 & 5,0 & 5,0 & 4,7 \\
\hline & saturation & 5,0 & 5,0 & 4,9 & 4,8 \\
\hline & Raw material correspondence & 5,0 & 5,0 & 5,0 & 4,7 \\
\hline & pureness & 4,9 & 4,9 & 4,9 & 4,9 \\
\hline \multirow{4}{*}{ Consistence } & Plasticity & 5,0 & 4,9 & 4,9 & 4,8 \\
\hline & elasticity & 5,0 & 5,0 & 4,9 & 4,7 \\
\hline & homogeneity & 5,0 & 4,9 & 5,0 & 4,7 \\
\hline & Fine-dispersion & 5,0 & 5,0 & 5,0 & 4,7 \\
\hline \multirow{4}{*}{ Color } & Saturation & 5,0 & 5,0 & 4,9 & 4,7 \\
\hline & Expressiveness & 5,0 & 4,9 & 5,0 & 4,7 \\
\hline & Raw material correspondence & 4,9 & 4,9 & 5,0 & 4,7 \\
\hline & Homogeneity & 5,0 & 4,9 & 5,0 & 4,7 \\
\hline
\end{tabular}

For improving the outlook of sandy cakes, it is promising to use different pastes, namely cream, strawberry, sour-cream, caramel and so on. For improving the consistence, it is expedient to use lecithin. The offered solutions need confirmation by the experimental method that is a promising task.

\section{Conclusions}

The studies are devoted to establishing the rational concentration of meals of soya, sunflower and milk thistle in a sandy dough semi-product. The chemical composition of correspondent meals was determined, and the optimal composition that is in ratio 3:4:3 was calculated. The quality esti- 
mation of meals was conducted, and their organoleptic parameters were analyzed. A possibility of using meals of soya, sunflower and milk thistle in the sandy shortcake technology was explained.

The sensor analysis of sandy semi-products of soya, sunflower and milk thistle meals was conducted. It was established, that the replacement of wheat flour in the flour confectionary products by meals in amounts from $10 \%$ to $30 \%$ unessentially influences the organoleptic parameters of developed sandy semi-products. Experimental samples are inferior to the control one by the unessential value. It has been determined, that it is rational for using in a sandy dough semi-product to add the composition of soya, sunflower and milk thistle meals in amount $20 \%$.

The advantage of using soya, sunflower and milk thistle meals in a sandy dough semi-product is the improvement of healthy properties of ready products. Among shortcoming there must be noted the unessential influence of meals on the organoleptic indices of developed sandy semi-products with the partial worsening of the outlook, color and consistence.

The conducted studies allow to use oilseed crop meals at producing sandy cakes. It will essentially improve their healthy properties and positive effect for the human organism. In further it is necessary to study ready sandy products for establishing their quality. It is also urgent to verify a possibility of using meals of other crops in sandy dough.

\section{References}

[1] Hurlimann, T., Peña-Rosas, J. P., Saxena, A., Zamora, G., Godard, B. (2017). Ethical issues in the development and implementation of nutrition-related public health policies and interventions: A scoping review. PLOS ONE, 12 (10), e0186897. doi: https://doi.org/10.1371/journal.pone.0186897

[2] Ali, A., Rahut, D. B. (2019). Healthy Foods as Proxy for Functional Foods: Consumers' Awareness, Perception, and Demand for Natural Functional Foods in Pakistan. International Journal of Food Science, 2019, 1-12. doi: https://oi. org/10.1155/2019/6390650

[3] Csapó, J., Némethy, S. (2018). Functional, health protecting and health maintaining food products. Ecocycles, 4 (1), $73-82$. doi: https://doi.org/10.19040/ecocycles.v4i1.114

[4] Vincourt, P. (2014). Research fields, challenges and opportunities in European oilseed crops breeding. OCL, 21 (6), D602. doi: https://doi.org/10.1051/ocl/2014043

[5] Temple, N. J. (2015). Strategic nutrition: a vision for the twenty-first century. Public Health Nutrition, 19 (1), $164-175$. doi: https://doi.org/10.1017/s1368980014003292

[6] Scientific Opinion on the safety of advantame for the proposed uses as a food additive (2013). EFSA Journal, 11 (7). doi: https:// doi.org/10.2903/j.efsa.2013.3301

[7] Berstad, A., Raa, J., Valeur, J. (2017). Functional food for functional disorders. Microbial Ecology in Health and Disease, 28 (sup1), 1281955. doi: https://doi.org/10.1080/16512235.2017.1281955

[8] Shydakova-Kameniuka, O. H., Lysiuk, H. M. (2009). Vyznachennia ratsionalnoho dozuvannia nasinnia lonu do pisochnoho pechyva. Prohresyvni tekhnika ta tekhnolohiyi kharchovykh vyrobnytstv restorannoho hospodarstva i torhivli, 1, 347-353.

[9] Dorohovych, A., Dorohovych, V., Mazur, L., Pisarets, O. (2018). Complex indicator of quality of sugars and sugar substitutes and their use in the production of confectionery products. Food Resources, 10, 88-100.

[10] Soto-Cerda, B. J., Duguid, S., Booker, H. (2014). Association mapping of seed quality traits using the Canadian flax. Academic research paper on Biological sciences, 344-352.

[11] Fratelli, C., Muniz, D. G., Santos, F. G., Capriles, V. D. (2018). Modelling the effects of psyllium and water in gluten-free bread: An approach to improve the bread quality and glycemic response. Journal of Functional Foods, 42, 339-345. doi: https://doi. org/10.1016/j.jff.2018.01.015

[12] Kravchenko, M., Yaroshenko, N. (2017). Study of food and energy values of new gingerbread types. EUREKA: Life Sciences, 5, 53-60. doi: https://doi.org/10.21303/2504-5695.2017.00421

[13] Lysiuk, H. M., Shydakova-Kameniuka, O. H., Fomina, I. M. (2009). Tekhnolohiya boroshnianykh kondyterskykh vyrobiv z vykorystanniam yadra soniashnykovoho nasinnia. Kharkiv: KhDUKhT, 145.

[14] Olteanu, M., Criste, R., Panaite, T., Bunduc, V., Panaite, C., Ropota, M., Mitoi, M. (2016). Study on the Efficiency of Grape Seed Meals Used as Antioxidants in Layer Diets Enriched with Polyunsaturated Fatty Acids Compared with Vitamin E. Revista Brasileira de Ciência Avícola, 18 (4), 655-662. doi: https://doi.org/10.1590/1806-9061-2016-0230

[15] Abramova, A. H. (2017). Zastosuvannia poroshku chornoplidnoi horobyny v tekhnolohiyi biskvitiv funktsionalnoho pryznachennia typu «Chervonyi oksamyt». Zdobutky ta perspektyvy rozvytku kondyterskoi haluzi: Mizhnarodna naukovo-praktychna konferentsiya. Kyiv: NUKhT, 126-128. 
[16] Adhikari, B., Howes, T., Bhandari, B. R., Truong, V. (2001). Stickiness in foods: a review of mechanisms and test methods. International Journal of Food Properties, 4 (1), 1-33. doi: https://doi.org/10.1081/jfp-100002186

[17] Horalchuk, A. B., Pyvovarov, P. P., Hrynchenko, O. O. (2006). Reolohichni metody doslidzhennia syrovyny i kharchovykh produktiv ta avtomatyzatsiya rozrakhunkiv reolohichnykh kharakterystyk. Kharkiv: KhDUKhT, 242.

[18] DSTU 3781:2014. Pechyvo. Zahalni tekhnichni umovy (2015). Kyiv: Derzhspozhyvstandart Ukrainy, 16.

[19] DSTU 4910:2008. Vyroby kondyterski. Metody vyznachennia masovykh chastok volohy ta sukhykh rechovyn (2008). Kyiv: Derzhspozhyvstandart, 16.

[20] DSTU 5024:2008. Vyroby kondyterski metody vyznachannia kyslotnosti ta luzhnosti (2008). Kyiv: Derzhspozhyvstandart, 16.

[21] TU U 10.4-38667335-002:2014. «Produkty pererobky z nasinnia oliynykh kultur. Tekhnichni umovy».

[22] Pavlov, O. (2018). Zbirnyk retseptur boroshnianykh kondyterskykh i zdobnykh bulochnykh vyrobiv. Kyiv: Profknyha, 336.

[23] DSTU ISO 5495:2004. Doslidzhennia sensorne. Metodologiya. Metod parnogo porivniannia (2004). Kyiv, Derzhstandart Ukrainy, 14.

[24] DSTU ISO 11035:2005. Doslidzhennia sensorne. Identuphikatsiya ta vybyrannia deskryptoriv dlia stvorennia sensornogo spektru za bahatobichnoho pidhodu (2008). Kyiv: Derzhspozhyvstandart Ukrainy, 27. 